\title{
Rola wyobraźni w procesie twórczym a zagrożenia współczesnego świata
}

\author{
Mariusz Dąbrowski, Agnieszka Chęć-Małyszek \\ e-mail: a.chec-malyszek@pollub.pl \\ Katedra Architektury, Urbanistyki i Planowania Przestrzennego, \\ Wydziat Budownictwa i Architektury, Politechnika Lubelska \\ Department of Architecture, Urban and Spatial Planning, \\ Faculty of Civil Engineering and Architecture, University of Lublin
}

\begin{abstract}
Streszczenie: We wszystkich obszarach aktywności twórczej wyobraźnia, jest niezbędnym elementem w życiu i funkcjonowaniu człowieka. W wielu sytuacjach życiowych jest ona nieodłącznym elementem wykorzystywanym w sposób mniej lub bardziej świadomy. Pozwala tworzyć wyobrażenia, które nie mają odpowiedników w żadnym z wrażeń, stanowiąc podstawę twórczości wszelkiej aktywności człowieka. Wyobraźnia jest naturalnym przedłużeniem wzroku, specyficzną zdolnością do wywoływania obrazów, pobudzającą do twórczego myślenia i działania. W dzisiejszych czasach człowiek nieustannie bombardowany jest coraz większą ilością dźwięków i obrazów, które „zagłuszają" naturalny rozwój wyobraźni. Szybki postęp technologiczny, którego jesteśmy świadkami, nie pozostaje bez wpływu na rozwój twórczego myślenia, tworzy bariery ograniczające człowieka.
\end{abstract}

Słowa kluczowe: wyobraźnia, twórcze myślenie, bariery, proces twórczy

\section{Wstęp}

Od wielu lat psychologowie i pedagodzy zajmują się badaniami nad wyobraźnią, gdyż dostarcza ona wielu niezbędnych informacji z życia artystycznego i psychicznego człowieka.

Od zawsze była ciekawym zagadnieniem dla wielu badaczy, będąc jedną z niewielu tak złożonych i wciąż nieznanych umiejętności. Posiadamy ją od dzieciństwa i właśnie w tym okresie uległa największemu rozwojowi. Pozwala młodemu człowiekowi na lepsze poznanie życia dorosłych oraz funkcjonowanie w społeczeństwie. Towarzyszy mu w każdym aspekcie życia, pozwalając na twórcze myślenie, komunikowanie się oraz marzenia na jawie i śnie.

Jak wiadomo każdy z nas jest różny i stanowi pewnego rodzaju indywidualność, również pod względem wyobraźni. U jednych rozwinięta jest ona na bardzo wysokim poziomie u innych na nieco niższym, często związane jest to z osobowością oraz wrodzonymi umiejętnościami człowieka. Chcąc wzbogacić i rozwinąć wyobraźnię niezbędna jest ciągła praca twórcza, która pobudza człowieka do myślenia i działania w wielu aspektach jego życia.

\section{Rysunek i malarstwo}

W starożytnej Grecji początkowo rysowanie, malowanie i pisanie określano słowem "graphein". Rysunek przeszedł bardzo radykalną reformę. Przestał być przedmiotem pomocniczym, uzupełniającym kształcenie malarzy, rzeźbiarzy czy architektów wnętrz, uznany został za autonomiczny język sztuki. Chociaż to jeden z najstarszych języków wypowiedzi artystycznej, przez całe wieki traktowany był w sposób służebny. Od początku historii sztuki istnieli znakomici artyści - rysownicy, ale dopiero w latach 70 XX wieku rysunek wyodrębniony został jako w pełni suwerenna dziedzina sztuk wizualnych. Już w czasach prehistorycznych rysunek był jedną z głównych form porozumiewania się między ludźmi. Początkowo była to sztuka przedstawiająca wyłącznie 
zwierzęta. W późniejszym okresie pojawia się mało realistyczny wizerunek człowieka przedstawiany w sposób niekompletny czy zredukowany do jednego segmentu ciała. ${ }^{1}$

Rysunek w dzisiejszych czasach nie zmienił się znacząco, nadal operuje kreską, lisią, walorem czy plamą. Przeobrażeniom nie ulegają też kanony proporcji postaci panujące w tamtych czasach jednocześnie stanowi on bogate źródło wiedzy o człowieku.

Malarstwo jest dokumentacją tego co znajduje się wokół, jak również prezentacją swoich wyobrażeń, snów i marzeń, daje artyście niezliczone możliwości wykorzystania swoich umiejętności oraz przedstawienia ich w dowolnej formie, stylu i podłożu. Jest dziedziną sztuki, która rozwijała się już w czasach prehistorycznych. Z odległych czasów paleolitu przetrwało do dnia dzisiejszego charakterystyczne malarstwo ścienne i jaskiniowe. Malarstwo prehistoryczne ukazywało sceny polowań, zaskakujące i ciekawie ujęcia postaci zwierząt i łowców. Cechowało się dokładnym, bardzo realistycznym odwzorowywaniem postaci zwierzęcych, podczas gdy postacie ludzkie malowane były zazwyczaj ledwie kilkoma pociągnięciami farby. Stosowano proste techniki malarskie, kontur malowano za pomocą barwników roślinnych lub nawet gliny, wypełniano go barwnikami w naturalnych odcieniach brązu, czerwieni i żółci. Z biegiem lat doskonalona była techniki, warsztat oraz rozbudowywana została tematyka obrazów. Sztuka starożytnej Grecji oraz Imperium Rzymskiego to głównie obrazy dekoracyjne przedstawiające bóstwa, z kolei średniowiecze to czas idealistycznego przedstawianie postaci. W rysunku ludzi nie przywiązywano wielkiej wagi do realizmu anatomicznego a osoby ważniejsze były ukazywane jako większe od pozostałych. Stąd liczne przekłamania w proporcjach ciała, „płaskość” postaci i obrazu (Ryc. 1 i 2).

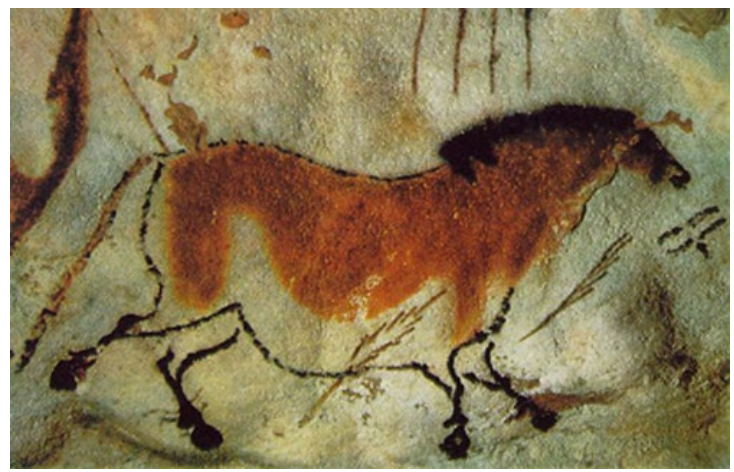

Ryc. 1. Naskalny rysunek konia z jaskini Lascaux we Francji. Źródło: https://pl.wikipedia.org/wiki/Lascaux_(Akwitania), 11.09.2016

Drawing a horse on the rock from the cave of Lascaux in France.

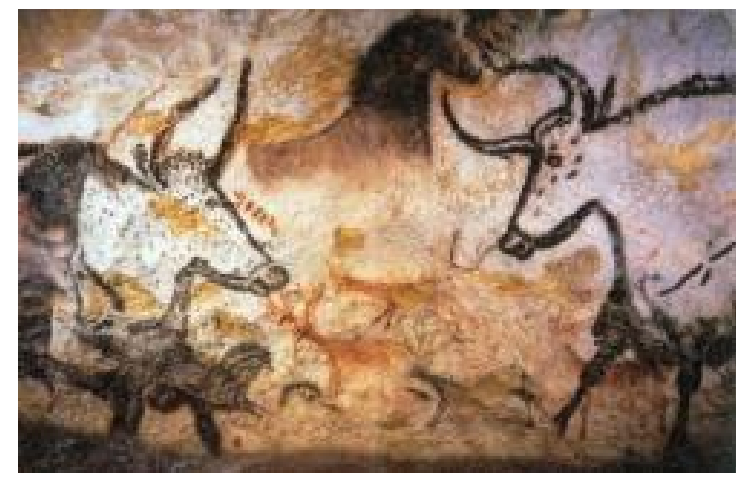

Ryc. 2. Scena z Sali byków, rysunek naskalny z jaskini Lascaux we Francji. Źródło: commons.wikimedia.org, 25.08.2012

The scene of the Hall of Bulls, drawing on the rock from the cave of Lascaux in France.

Realizm to cecha gotyku gdzie utrzymuje się tendencja do poruszania tematyki religijnej jednak styl wypowiedzi zmienia się, malarzom bardziej zależało na podkreśleniu indywidualizmu postaci. Z czasem gotyk wyparty zostaje przez jeszcze bardziej realistyczny renesans, gdzie dużą wagę przywiązywano do precyzji i harmonii. Barok to już nastawienie na wyrażanie uczuć a postacie zaczynają być przedstawiane w ruchu. ${ }^{2}$

Obecnie malarstwo często łączy się z obiektami tradycyjnie uważanymi za obce. Techniki mechaniczne i elektroniczne pozwoliły na powstanie hiperrealizmu oraz dużo swobodniejsze tworzenie dzieł. Malarstwo końca XX wieku jest często wyrazem określonej ideologii, a nie czystego zamysłu estetycznego. Wydawać by się mogło, że "tradycyjne malarstwo", kojarzone z realistycznym malarstwem figuratywnym, nie ma już swojego miejsca w świecie. Wielu estetyków jest wręcz zdania, że możliwości stojące przed malarstwem wyczerpały się, jako że nie ma już właściwie żadnego pola na innowację. Pogląd ten stoi jednak w sprzeczności z potrzebą tworzenia. ${ }^{3}$ 


\section{Problem wyobraźni w literaturze pedagogiczno-psychologicznej}

Pojęcie wyobraźni zostało zdefiniowane wielokrotnie przez wielu badaczy i naukowców a w szczególności psychologów, których problem ten bardzo intrygował. Spośród wielu definicji, które funkcjonują w literaturze, głównie psychologicznej, problem wyobraźni nie został jednoznacznie określony i po dziś dzień jest przedmiotem dalszych badań. Większość psychologów sądzi, iż wyobraźnia jest procesem złożonym, wchodzącym w wielorakie zależności z innymi właściwościami psychiki ludzkiej. Chcąc przedstawić trudności z definiowaniem tego pojęcia należałoby zaprezentować poglądy różnych autorów, w których uwzględnione są związki wyobraźni z innymi procesami psychicznymi.

W.Wundt postrzegał wyobraźnię za podstawowy składnik wszelkiego talentu, uważał iż jest ona siłą psychiczną tworzącą nowe obrazy, które mogą być związane z myśleniem bądź intuicją. Wielu psychologów uważa wyobraźnię za główną siłę psychiki ludzkiej, którą należy dogłębnie poznać. Niektórzy autorzy redukowali pojęcie wyobraźni do zespołu właściwości psychicznych warunkujących występowanie zjawisk twórczości i utożsamiali ją z myśleniem twórczym.

J. Klimczyk pisał, że „procesu psychicznego dokonującego się wyobraźni” nie można utożsamiać z pamięcią, ani z myśleniem, gdyż nie każda pamięć ma charakter obrazowy i nie każdy rodzaj myślenia polega na operowaniu obrazami. Gdybyśmy z wyobraźni chcieli usunąć inne towarzyszące jej procesy psychiczne, to musielibyśmy przyjąć, że właściwą wyobraźnią będą obrazy zmiennie następujące po sobie w sposób samorzutny, bez udziału naszej woli [...] $]^{4} Z$ tego stwierdzenia możemy wywnioskować, iż z wyobraźnią odtwórczą współdziała pamięć, a z wyobraźnią twórczą współdziałają procesy myślowe. W. Witwicki przyjmuje, że „wyraz wyobraźnia obejmuje to, co się krótko nazywa pamięcią zmysłową, jak i to, co nosi nazwę wyobraźni twórczej. ${ }^{5}$

Zdaniem W. Gloksina wyobraźnia jest zdolnością tworzenia w świadomości ciągów wyobrażeń nie stanowiących kopii zdarzeń, kopie przeminęły, lecz twórcze powiązanie i uzupełnienie ich śladów pamięciowych pozostało. W ten sposób uzyskujemy bardziej wyrazisty sposób zależności między wyobraźnią a pamięcią. ${ }^{6}$

Myślenie w sposób silny związane jest z wyobraźnią i tak W. Łukaszewski uważa, że „odróżnianie myślenia od wyobraźni ma swój sens wyłącznie w odniesieniu do operacji reprodukowanych, które w przypadku wyobraźni są istotnie obrazowe, a w przypadku myślenia mogą takie nie być. Rozróżnienie to traci sens wtedy, gdy mowa jest o myśleniu i wyobraźni produktywnej, twórczej" ${ }^{77}$. Ścisły związek wyobraźni z myśleniem podkreślają - O. Kondas, według którego, „Istnieje ścisły związek między wyobraźnią a myśleniem”8 oraz S.L. Rubinsztejn, który pisał „Aby jednak przekształcać rzeczywistość w praktyce trzeba umieć przekształcać ją w myśli." ${ }^{9}$

Według M. Tyszkowa „Wyobraźnia jest ważnym elementem procesów poznawczych, a szczególnie twórczego myślenia"10. Jak stwierdza K. Sławska, "myślenie łatwo przechodzi od jednego określania do drugiego, rozpatruje przedmiot jednocześnie z wielu stron i dlatego można je uchwycić we wszystkich jego sprzecznościach. ${ }^{11}$

„Współzależność twórczego myślenia, wyobraźni i różnych form intuicji intelektualnej jest istotnie skomplikowana i być może w przyszłości trzeba będzie zrezygnować z niektórych terminów"12. Rolę myślenia intuicyjnego w procesie twórczym podkreśla również W. Dobrołowicz „rola wyobraźni w odróżnieniu od myślenia ujawnia się między innymi w tym, że umożliwia ona łączenie nie tylko odległych, ale nawet sprzecznych, antagonistycznych elementów doświadczenia. ${ }^{13}$ E.D. Berlyne jest zdania, że „zdarzenia, które nie były spostrzegane, mogą być reprodukowane w wyobraźni tylko wówczas, jeżeli dana osoba dysponuje reakcjami transformacyjnymi, które pozwalają wyobrazić sobie te zdarzenia." ${ }^{14}$

10 M. Tyszkowa, Baśń w życiu i rozwoju dziecka, „Wychowanie w Przedszkolu”, 1974, nr 4, s. 199

11 K. Sławska, Myśl w działaniu - psychologia myślenia, Warszawa 1971, s. 171-172

12 A. Nałczadżjan, Intuicja a odkrycia naukowe, Państwowy Instytut Naukowy, 1979 Warszawa, s. 46-47

13 W. Dobrołowicz, O myśleniu intuicyjnym, "Studia Filozoficzne”, 1981, nr U, ss. 105-121

14 E.D. Berlyne, Struktura i kierunek myślenia, Warszawa 1969 
J.L. Singer pisze: „Wydaje się, że na wyobraźnię należy spojrzeć nieco szerzej, widząc w niej pewien generalny sposób reagowania na otoczenie, pewną możliwość dostępną wielu ludziom, którzy w rozmaitych sytuacjach społecznych bywają stłumieni i kontrolowani. Dałoby się ponadto wykazać, że istnieje wiele osób, które - jak na to wskazuje test Rorschacha - są nie tylko zdolne do wybujałej gry wyobraźni, ale potrafią także być ogromnie ekspresyjne i emocjonalne. Są to jednostki w równym stopniu energiczne i aktywne, pełne fantazji oraz wyobraźni, które - jak się wydaje - zawsze potrafią dobrać odpowiedni moment, by w sposób efektywny dać upust swej naturze”"15. L.Singer termin "wyobraźni” i "marzenia” traktuje jako synonimy, posługując się takimi pojęciami przy ich opisywaniu, jak „marzenie”, „wyobraźnia”, i „fantazja”. Zdaniem L. Wygotskiego, "uczucie i fantazja nie stanowią dwóch odrębnych procesów, lecz w istocie są jednym i tym samym zatem mamy prawo traktować fantazję jako centralny wyraz reakcji emocjonalnej.

M.Grzywak-Kaczyńska uważa, iż bardzo ważną rolę w procesie kreowania wyobraźni odgrywają marzenia. „Życie w marzeniach, czyli realizowanie różnych pragnień nie w rzeczywistym działaniu, lecz fikcyjnie, odgrywa pewną rolę w życiu każdego człowieka [...]. Każdy z nas przeżywa też w wyobraźni zdarzenia korygując, kształtując je zgodnie ze swymi pragnieniami. Często ludzie kompensują sobie marzeniami braki swego rzeczywistego życia"16.

"Wszystkie wytwory wyobraźni twórczej są wytworami fantazji”. „Ktoś może wpadać na pomysł niebywały, ale przeżywa go nie obrazowo, ten ma fantazję, ale nie posiada wyobraźni twórczej". ${ }^{17}$

\section{Rodzaje i cechy wyobraźni}

Th. Ribot już na początku XX wieku sklasyfikował i wyróżnił kilka rodzajów wyobraźni takich jak: intuicyjna, samorzutna, kombinująca, rozumowa oraz najszerzej opisana i chyba najlepiej wszystkim znana, twórcza. ${ }^{18}$ Przypisuje on wyobraźni twórczej ogromną rolę w procesie kreacji.

P.E. Vernon wyróżnia wyobraźnię wzrokową, ruchową i słuchową, które zalicza do strukturalnych zdolności człowieka. ${ }^{19}$ Wśród rozróżnienia zaproponowanego przez P.B. Verona na największą uwagę zasługuje wzrokowa, która odgrywa czołową rolę w spostrzeganiu procesu twórczego jak w kreacji plastycznej jednocześnie nie uwzględnia takich rodzajów wyobraźni jak dotykowa, smakowa czy węchowa.

Istotne rozróżnienie zaproponowane przez W. Witwickiego dotyczy wyobraźni "konkretnej” oraz „oderwanej", mniej ważne miejsce w tym podziale pełni "wyobraźnia oderwana”. Z kolei przypisuje się wyobraźnię „Wzrokową" twórczości malarskiej i plastycznej. „Dotykowa”, wynika z bezpośredniego kontaktu z przedmiotem bierze czynny udział w tworzeniu niektórych dzieł sztuki współczesnej i ich odbiorze.

Inne rozróżnienie to wyobraźnia "realistyczna" a jej przeciwstawna "senna". Pierwsza "dająca się odtworzyć rysunkiem bądź modelem" a druga to obrazy mgliste, sprzeczne, majaczące nie dające się odtworzyć. ${ }^{20}$ M. Przetacznikowa i G.M. Jarża pisały „marzenia senne to obrazy przeżywane w śnie [..] przypadkowe, często dziwaczne i fantastyczne". ${ }^{21}$ Istnieją zatem ludzie, których sny są bardzo realistyczne i są w stanie odtworzyć swoje wizje senne z bardzo dużą dokładnością. Zdaniem O. Kondasa "większość snów wiąże się z wyobraźnią wzrokową". ${ }^{22}$ A więc wynika z tego, iż istnieje możliwość przechodzenia z jednego rodzaju wyobraźni w inny pod wpływem określonych "stanów psychicznych

A.T. Troskolański uważa, że do twórczości w dziedzinie techniki niezbędna jest „wyobraźnia kinetyczna”, która wywołuje w myślach obraz ruch, oraz dynamiczna, polegająca na wywoływaniu siły i momentów działających

\footnotetext{
15 J.L. Singer, Marzenia dzienne, Warszawa, 1980, s. 152-153

16 M. Grzywacz- Kaczyńska, Psychologia dla każdego, Warszawa, s. 91

17 W. Witwicki, Psychologia, t.l, Warszawa 1962, s. 330

18 Th. Ribot, O wyobraźni twórczej, Warszawa 1901, s. 112

19 B. Hornowski, Rozwój inteligencji i uzdolnień specjalnych, Warszawa 1978, s. 102

20 W. Witwicki, Psychologia, t.l, Warszawa 1962, s. 336-340

21 M. Przetacznikowa, G. M. Jarża, Psychologia...op.cit.,s. 102

22 O. Kondas, Psychologia kliniczna, Warszawa 1984, s. 181
} 
na poszczególne człony mechanizmu. ${ }^{23}$ T.W. Nowicki uważa, że dla twórczości technicznej „wartość ma ten rodzaj wyobraźni, który nazywa się wyobraźnią przestrzenną i techniczną". ${ }^{24}$

I. Rozet dokonał rozróżnienia na wyobraźnię twórczą i odtwórczą, „pozwala wyznaczyć zakres faktów i problemów podlegającym badaniu. ${ }^{25}$ Według Th. Ribota „wyobraźnia twórcza, jak ją zwykle określamy, jest czymś nadzwyczaj złożonym. W wyobraźni twórczej mamy wiele współdziałających wyobrażeń, które w rozmaity sposób kombinują się, układają i przekonują" a reguluje ją świat wewnętrzny. ${ }^{26}$ Wyobraźnia twórcza, zależy od chłonności i wrażliwości człowieka na piękno oraz harmonię kształtów. ${ }^{27}$

„Wyobraźnia kształtowana jest w procesie działalności twórczej [...] istnieje tyle różnych rodzajów wyobraźni ile jest swoistych rodzajów ludzkiej działalności konstrukcyjnej, technicznej, naukowej, artystycznej czy muzycznej." 28

Problem wyobraźni jest bardzo szeroko opisany przez wielu autorów wyżej wymienionych, stąd tak wiele różnych teorii związanych z wyobraźnią, tak bardzo się różniących. Jednak spośród tak wielu na uwagę zasługuje wyobraźnia "wzrokowo-percepcyjna”, "dowolna” w której skład wchodzą "spontaniczna” i „świadomie inspirowana”, wyobraźnia „twórcza” i „odtwórcza. Jeśli mówimy o cechach charakteryzujących wyobraźnię to należało by tutaj wymienić Th. Ribota, który uważał, że „wszelkie odtwarzanie jest powtarzaniem, podczas gdy wyobraźnia twórcza daje nam coś nowego i to jest jej istotną oraz cechą." ${ }^{29}$ "Jeśli odtwarzanie jest główną cechą pamięci, to przekształcenie stanowi główną cechę wyobraźni" ${ }^{30}$. Ważną cechą wyobraźni jest jej retrospektywny oraz prospektywny charakter." ${ }^{13}$

A więc cechą bogatej wyobraźni jest przede wszystkim łatwość, szybkość i oryginalność wytwarzania nowych obrazów.

\section{Wyobraźnia w twórczości}

W podręcznikach psychologii wyobraźnię ujmuje się najczęściej jako zdolność do tworzenia obrazów umysłowych $^{32}$. Większość psychologów wyróżnia co najmniej dwa rodzaje wyobrażeń: odtwórcze oraz twórcze. Za wyobraźnię twórczą uważa się te obrazy, które charakteryzują się oryginalnością pomiędzy różnymi elementami zapamiętanej rzeczywistości, posiadające walory kreatywne stając się jednocześnie podstawowym źródłem twórczości artystycznej. Z kolei wyobraźnia odtwórcza, która powstaje na bazie śladów pamięciowych, wiernie odtwarza zapamiętywaną rzeczywistość. Psychologowie usytuowali wyobraźnie pomiędzy takimi zdolnościami jak pamięć oraz myślenie, gdyż istnieje między nimi wspólna zależność. W pierwszym okresie życia człowieka znacznie przeważa wyobraźnia twórcza z wiekiem te proporcje się na ogół odwracają. Wyjątek stanowią artyści, u których wyobraźnia twórcza dominuje nad odtwórczą zarówno w działalności społecznej jak i zawodowej. Wielu uczonych uważa, iż w procesie kreowania wyobraźni znaczącą rolę odgrywa wzrok. Według J. Bronowskiego wyobraźnia wyznacza rodzaj następstw, w jakich myślimy o rzeczach pojawiających się w umyśle. Jednocześnie jest darem o wiele mniej mechanicznym niż zdolności oka i chociaż zakorzeniona w zmyśle wzroku, to jednak znacznie wykracza poza jego możliwości ${ }^{33}$.

W życiu każdego człowieka wyobraźnia odgrywa znaczącą role w funkcjonowaniu w społeczeństwie. Dla projektantów jest ona narzędziem oraz źródłem pracy, dla dziecka jest źródłem zabawy oraz ekspresji artystycznej, zaś dla zwykłego człowieka jest źródłem wzbogacania, koloryzowania i upiększania codzienności życia. Do

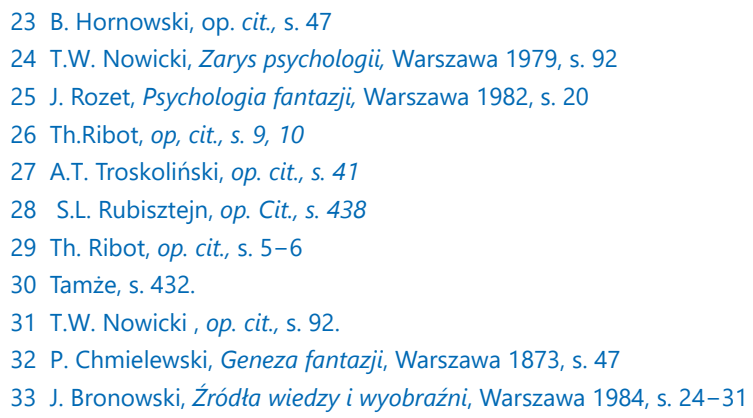


prawidłowego funkcjonowania każdego człowieka w społeczeństwie wyobraźnia jest mu niezbędna. Dzięki niej może on przewidywać reakcje u innych ludzi oraz następstwa aktualnie podejmowanych działań.

Sztuka ma duży wpływ na rozwój wyobraźni moralnej człowieka, uczestnicząc jednocześnie w wydarzeniach będących treścią dzieł artystycznych. W ścisły sposób związana jest z uwagą, emocjami, empatią czy intuicją, powodując integrację oraz współdziałanie różnych procesów psychicznych. Wpływa na myślenie logiczne, wyznaczając kierunek aktywności i analizy logicznej.

Twórczość ma swe źródło w wyobraźni jest realizacją pewnych pragnień, poprawieniem niezadowalającej rzeczywistości powoduje zastępczą formę działania człowieka. Uważa się ją za jeden z najistotniejszych elementów różniących ludzi między sobą, gdyż jest zdolnością niepowtarzalną a produkty twórcze uznawane są za oryginalne..$^{34}$

Jeśli mówimy o rozwoju wyobraźni po przez sztukę, rozróżniamy dwie drogi do niej prowadzące, po przez bezpośredni kontakt z dziełem oraz własną działalność artystyczną. Istnieją jednak biopsychiczne i społeczne bariery rozwoju wyobraźni. S. Szuman pisał, że nie można w człowieku ukształtować zupełnie nowych zdolności psychicznych, muszą istnieć zadatki wrodzone, które mogą rozwinąć się pod wpływem oddziaływań pedagogicznych $^{35}$. Inne ograniczenia znajdujemy w środowisku, w którym żyje dana jednostka. Wyobraźnia powinna być przede wszystkim wyzwalana i kultywowana, pobudzana, usprawniana oraz dążyć do wydobywania z niej najgłębszych możliwości twórczych. Wielu uczonych i badaczy uważa, iż przebywając w otoczeniu wybitnego człowieka, pobudzana jest wyobraźnia, która przyczynia się do wzrostu poziomu twórczości danej osoby.

Współcześnie wyobraźnia zajmuje kluczowe miejsce w kategoriach estetycznych oraz wychowawczych. Za nauczycielkę wyobraźni możemy uznać sztukę, z którą wiąże się również zagadka ludzkiego losu czyli bunt przeciwko zastanej rzeczywistości. ${ }^{36}$ Źródłem tego buntu jest właśnie wyobraźnia, która w ten sposób dąży do pokazania niezadowolenia z realnego świata. Problem związku sztuki z wyobraźnią znany jest już od starożytności, ale przedmiotem szczegółowych badań stało się dopiero w XVII stuleciu. Zaczęto wtedy analizować strukturę i przebieg procesu twórczego. Kopiowanie rzeczywistości wymagało od malarzy XVII i XVIII wieku wyostrzonego wzroku, kreatywności oraz nie przeciętnych zdolności manualnych. Sztukę zaczęto analizować według nowych reguł, gdzie uznawano wyobraźnię za centralne pojęcie tej dziedziny, zastępując jednocześnie takie terminy jak, rozum, kanon czy proporcja. W dwojaki sposób próbowano przedstawić istotę funkcjonowania wyobraźni z jednej strony filozofowie z drugiej artyści. Filozof G. Vico uważał, iż dzięki wyobraźni twórca tworzy dzieło i wciela się w nie, uprzedmiotawiając swą podmiotowość. Wyobraźnia przywołuje wspomnienia, które dopiero później opracowuje intelekt ${ }^{37}$. Próbował on znaleźć jedną zasadę procesu twórczego dopatrując się jej w wyobraźni, poprzez aktywność poety. Inny filozof Ch. Baudelaire niejako podciął "korzenie" łączące dotychczasową sztukę z życiem. Traktował ją jako autonomiczny świat spełniania wyobraźni człowieka, niezależny od jego związków z realnym życiem. Pisał między innymi, że świat fikcji artystycznej jest tak samo niezbędny ludziom, jak świat rzeczywisty ${ }^{38}$.

Główny nurt rozważań artystów i filozofów w XVIII i XIX wieku dotyczył ustalenia zależności pomiędzy cechami osobowości twórcy a strukturą jego dzieła. Wyobraźnię traktowali oni jako źródło twórczości, albo bardzo ważny jej element, umożliwiający poznanie sztuki. I. Kant uważał, iż jest dyscypliną niezbędną do prawidłowego funkcjonowania, każdego człowieka w społeczeństwie. Istota polegała na przekształcaniu nowego obrazu opierając się na uprzednich spostrzeżeniach, ściśle związanych z wyobraźnią. Według niego, wyobraźnia bierze czynny udział w procesie poznawania rzeczywistości, ułatwiając jednocześnie rozpoznawanie i nazywanie przedmiotów. Jest więc formą zbliżenia obrazów do pojęć, jednocześnie ma związek z intelektem i spostrzeżeniami. ${ }^{39}$

Rolą wyobraźni jest umożliwienie i scalenie różnych wartości uniwersalnych z wartościami życia codziennego. To ona jest podstawowym składnikiem ludzkiej świadomości, i dzięki niej artysta jest w stanie przenikać strukturę tworzywa. W sztuce posługuje się ona przestrzenią oraz pozwala odbiorcy właściwie ująć te kategorie, które w swej istocie są projekcją intuicji. W koncepcji S. Maimona wyobraźnia jest najbardziej oryginalnym

\footnotetext{
34 J. Górniewicz, Wstęp do pedagogicznej analizy problematyki wyobraźni, Toruń 1991, s. 26

35 S. Szuman, O budzeniu i pogtębianiu wrażliwości młodzieży na sztukę, Nowa Szkoła" 1961 nr 5

36 B. Suchodolski, Wychowanie i strategia życia, Warszawa 1983, s. 183

37 G. Vico, Nauka nowa, Warszaw 1966, s. 475-476

38 Ch. Baudelaire, Szkice krytyczne, Wrocław 1961, s. 93-96

39 J. Kant, Krytyka władzy sądzenia, Warszawa 1986, s. 124-129
} 
uzdolnieniem człowieka. Wszystko, co jest poza nią w jego umyśle, można traktować jako prosty refleks biologicznego dziedzictwa dzięki, której powstaje sztuka. ${ }^{40}$

W. Blake uważał, iż wyobraźnia jest formą marzenia dzięki, której ludzie mogą snuć przypuszczenia dotyczące ich przyszłości. Cele do których pragną dążyć, stają się bliskie i możliwe do realizacji właśnie dzięki niej a źródłem marzeń jest często sztuka. Odbiorcy poszukują w niej prawdy o życiu oraz uczuciach, których często skąpiło im życie. W sztuce poszukują prawdy o życiu, których im braknie. Wyobraźnia artysty tworzącego dzieło sztuki wzbogaca świat zapewniając jednocześnie doznania estetyczne odbiorcy ${ }^{41}$. Inspirująca rola wyobraźni w twórczości artystycznej wskazuje jednocześnie na jej integralny charakter z innymi zdolnościami człowieka oraz z wartościami uniwersalnymi. Część z filozofów i artystów utożsamia wyobraźnię z samym aktem kreacyjnym, uważają że sztuka zaczyna się tam gdzie pojawia się dzieło czyli moment poczęcia w wyobraźni artysty.

Wyobraźnia utożsamiana jest z aktem twórczym. Artysta nie ogranicza się do kopiowania natury, lecz interpretując ją, tworzy nową rzeczywistość - wyobrażeniową. ${ }^{42}$ Najpełniejszy wyraz utożsamiania wyobraźni z aktem twórczym dokonał P.B. Shelley wyrażając przekonanie, że poeta czerpie z wyobraźni swe natchnienie i zapłatę ${ }^{43}$. Natchnienie wygasa w momencie rozpoczęcia aktu kreacyjnego będącego pierwszym impulsem do twórczości przez co życie ludzkie uzyskuje nowe wymiary. Wyobraźnia jednego człowieka wzbogaca wyobraźnię innych osób stając się źródłem i narzędziem aktu tworzenia "Sztuka bowiem jest efektem dyskusji wielu pokoleń artystów, którzy dążą do objawienia w niej prawdy życia ${ }^{44}$. J.G. Sulzera wyraził pogląd, iż "matką wszystkich sztuk jest właściwie wyobraźnia. Dzięki niej artysta wyróżnia się wśród innych ludzi tak, jak filozof dzięki rozumowi". ${ }^{45}$ W. Humboldt przyjął powyższą tezę jako podstawę własnej estetyki i oparł ją na jednej tylko kategorii - wyobraźni. Podjął w ten sposób próbę przezwyciężenia ograniczeń „obowiązującej” estetyki poprzez skonstruowanie całej teorii wokół zagadnienia twórczej wyobraźni. Rozdzielił sztukę i rzeczywistość. Według W. Humboldta artysta nie powinien czerpać swych odczuć z natury, lecz wyłącznie z wyobraźni. ${ }^{46} \mathrm{~A}$ więc droga do twórczości wywodzi się od umysłu a nie od zmysłów.

llu teoretyków tyle teorii ujęcia przez nich wyobraźni w procesie twórczym. Wyobraźnie rozumiano jako splot procesów psychicznych stanowiących wewnętrzną strukturę twórczości, utożsamia się ona z samym aktem kreacji. Stała się zasadniczym źródłem twórczości wyznaczając jednocześnie jej poziom i zasadniczą kategorią estetyki. I. Kant pisał, iż wyobraźnia jest niezbędna w rozumieniu i odbieraniu sztuki, gdyż nie można odczytać zamiaru artysty bez wcześniejszego odczucia pewnych wartości dzięki wnikliwej interpretacji. J. Ruskin uważał, że dzięki wyobraźni odbiorca odczytuje idee twórców a nie powtarza już wcześniej wymyślonych kształtów ${ }^{47}$. Pomaga w zrozumieniu dzieła sztuki nie zależnie od epoki, w której ono powstało, dzięki czemu ludzie mogą odczytać wartości estetyczne i cieszyć się jego pięknem.Jednocześnie przyczynia się nie tylko do powstawania nowych rzeczy, lecz także rzeczom istniejącym nadaje nowe oblicze, obniżając bądź podwyższając ich jakość.

Jeden z kontynuatorów myśli I. Kanta, J. Frohschammer określił wyobraźnię jako główną zasadę rozwijającego się wszechświata, jest ona obecna w każdej czynności logicznej umysłu stale ingerując w strukturę zastanego świata. ${ }^{48}$ Twórca przekształca materiał z natury w ideał, a punktem wyjścia twórczości artystycznej jest rzeczywistość, w której funkcjonuje artysta. Wyobraźnia ingeruje w nią, nadając jej poszczególnym egzemplarzom nowe znaczenie. Źródłem wyobraźni jest natchnienie, treścią uczucie ${ }^{49}$.

Różne są więc sposoby rozumienia wyobraźni, coś stwarza, przemienia rzeczywistość, ułatwia w rozumieniu tego co stworzyła i ciągle to zmienia. Jest źródłem twórczości artystycznej, niezbędnej w procesie spostrzegania wartości sztuki i rekonstrukcji rzeczywistości.Gdy sztukę zaczęto ujmować w kategoriach „stylu życia” wówczas wyobraźnia stała się źródłem i terenem aktywności człowieka wyznaczając funkcje oraz treści. Odgrywa

40 N.J. Jacobs, Maimon's Theory of the Imagination, (w) Studies in Philosophy Jerusalem 1960, s. 250-257

41 Por. M. Bobra Sangs of Innocence and Experience, (w) Romantic Imaginacjon, London 1961, s. 25-31

42 E. Young, Propozycje dotyczące oryginalnej twórczości, (w:) Teoria ba dań literackich za granica Antologia, t. 1, (Wybór i opracowanie S. Skwarczyńska), Kraków 1965, s. 165

43 P. B. Shelley, Obrona poezji, (w) Manifest romantyzmu 1790-1830 Op. cit., s. 101

44 Tamże, s. 11

45 Tamże, s. 17

46 J. Rukin, O wyobraźni (w) Sztuka - Społeczeństwo - Wychowanie, Wrocław 1977, s. 49-50

47 Z. L. Zakski, Rola wyobraźni w twórczości naukowej, Hanower 1946, s. 9-10

48 Por. S. Morawski, Poglądy Józefa Kremera na sztukę, (w:) Studia historii myśli estetycznej XVIII i XIX w., s. 260

49 J. Ruskin, O wyobraźni, Op.cit., s. 63 
potężną role w moralności gdyż czym jest artysta i sztuka, tworzeni bez cnoty i wyobraźni,. J. Rsukin piała, że wyobraźnia twórcy oddziałuje wprost na wyobraźnię odbiorcy a jedynie człowiek o bogatej wyobraźni potrafi należycie odebrać wartości dzieła sztuki. ${ }^{50}$

Wyobraźnia uważana jest za nauczycielkę sensu moralnego barwy, linii, dźwięku i zapachu u człowieka. Tworzy ona świat nowy, jest „królową prawdy” bez niej wszystkie zdolności nie istnieją. Jest tym potężniejsza im lepiej wspomagana, staje się wtedy najmocniejszą bronią w walce z ideałem. ${ }^{51}$ Potrafi złamać każdą regułę czy konwencję, jest "oknem na świat" w którym dzieła sztuki i elementy wchodzące w jej skład istnieją niezależnie od twórcy, a siła twórcza którą posiada polega na jego otwarciu. Umożliwia tworzenie świata innego. Uświadamia że istnieją postacie, sytuacje, barwy, dźwięki, melodie, kształty nie zdarzające się w życiu codziennym, a stanowiące obszary ucieczki, zakresy radości bądź możliwości wzruszenn. ${ }^{52}$

Autorzy są zgodni co do tego, iż wiele operacji umysłowych w szczególności tych związanych z procesem twórczym, dokonywanych jest na wyobraźni wizualno-przestrzennej. Zatem jest ona nieodzownym elementem naszego umysłu, a co za tym idzie naszego życia. Pomaga nam interpretować zwykłe zjawiska w sposób dla nas indywidualny i osobliwy. Artystompomaga w tworzeniu dzieł a odbiorcom w ich głębszym zrozumieniu i lepszym odbiorze.Przyczynia się do upiększania naszego życia i otaczającego nas świata powodując że staje się on piękniejszy, bardziej dostępny i lepiej zrozumiały.

\section{Rola wyobraźni w procesie twórczym}

Wyobraźnia to proces tworzenia nowego obrazu lub rzeczywistości, idei, pomysłu, wizji czy przekształcenia. ${ }^{53}$ „Wyobraźnia nie powtarza ani nie naśladuje niczego mechanicznie.."54 Odgrywa ona ważną rolę we wszelkiej aktywności twórczej człowieka zarówno związanej ze sztuką, jak również z działalnością naukową, techniczną czy społeczną, jest ona zarówno procesem umysłowym, który angażuje myślenie metaforyczne o silnym zabarwieniu efektywnym. ${ }^{55}$

W wielu psychologicznych koncepcjach przyjmowano, że jest ona zdolnością kojarzenia różnych danych zmysłowych oraz idei w umyśle postrzegającego. Odgrywa czołową rolę w procesie rozumienia świata i człowieka a dla niektórych badaczy stanowi główną siłę psychiki ludzkiej. ${ }^{56}$

W wielu publikacjach psychologicznych wyobraźnia to zdolność do tworzenia nowych obrazów z wcześniej zapamiętanych fragmentów otaczającej rzeczywistości, aktywizujących psychikę ludzką do działania. ${ }^{57}$

Wyobraźnia zaliczana jest do zdolności specjalnych ściśle powiązanych z określoną działalnością twórczą, jest ona również określana mianem fantazji czy wyobraźni twórczej będąc jednocześnie wymiennym elementem zdolności plastycznych. ${ }^{58}$

Jest ścisłe powiązana z twórczości a zależność między nimi polega na kształtowaniu jej w procesie działalności twórczej. ${ }^{59}$ Powstało bardzo wiele definicji odnośnie procesu twórczego i wielokrotnie były one zmieniane i unowocześniane. Ilu uczonych, psychologów tyle definicji, z których można wyciągnąć podobne wnioski odnośnie procesu twórczego. Jest to szereg ukierunkowanych czynności psychicznych i fizycznych, mniej lub bardziej uświadomionych przez podmiot tworzący, w wyniku czego następuje ekspresja własnej osobowości poprzez dokonywanie zabiegu przekształcenia rzeczywistości zewnętrznej i własnego "ja". ${ }^{60}$

\footnotetext{
50 Tamże, s. 54-66

51 Tamże.

52 J. Szczepański, Sprawy ludzkie, Warszaw 1984, s. 147-149

53 M. Łuszczak, Możliwości kształtowania wyobraźni twórczej studentów, Cieszyn 1997, s. 51

54 Tamże, s. 51

55 S. Popek, R. Tarasuk, pod red., U podstaw edukacji plastycznej, Lublin 2000, s. 86

56 J. Górniewicz, Wstęp do pedagogicznej analizy problematyki wyobraźni, Toruń 1991, s. 22

57 Tamże, s. 24-25

58 M. Łuszczak, Możliwości kształtowania ...,Cieszyn 1997, s. 47

59 S.L. Rubinsztejn, 1962, s. 438

60 Tamże, s. 33
} 
Myślenie twórcze jest cechą charakterystyczną twórców zdolnych, dzięki czemu są oni w stanie rozwiązywać problemy nowe i nietypowe te z kolei, charakteryzuje się duża oryginalność i generatywność. ${ }^{61}$ Wszelka twórczość jest działaniem świadomym polegającym na rozwiązywaniu problemów natury artystycznej, która powinna być rozwiązywana kolejnymi etapami rozumowania twórczego.

W twórczości artystycznej dużą rolę odgrywa myślenie intuicyjne, pojmowane jako skrócony akt analizy i generalizacji. Intuicja odnosi się tu do procesu szybkiego spostrzegania, wyobrażania, zdrowego myślenia, czy oświecenia umysłu. Intuicja według H. Selyea jest ikrą dla wszystkich form oryginalności, przejawów inwencji, pomysłowości jest impulsem potrzebnym do połączenia świadomej myśli z wyobraźnią. ${ }^{62}$

Dla jednych proces twórczy prowadzi do powstania nowego dzieła dla innych jest procesem przetwarzania stanu świadomości. Dla innych jest burzenia pewnych układów i tworzenia na ich miejsce nowych i lepszych. A wiec twórczość jako proces pojmowana jest afirmacją życia ludzkiego. ${ }^{63}$

O procesie twórczym możemy mówić w ujęciu psychoanalizy i psychologii jako jawiącej się spontanicznej, nieuświadomionej dążności do samo urzeczywistnienia przez działanie, którego wynikiem są wytwory nieświadomej i świadomej sfery osobowości. ${ }^{64}$

A wiec proces twórczy sprzyja rozwojowi osobowości, a człowiek wzbogacony o te cechy charakteryzuje się twórczą postawą w codziennym działaniu. ${ }^{65}$

Jako pierwszy T. Ribot stworzył model procesu twórczego rozpatrując związek pomiędzy wyobraźnią a twórczością. Model ten składał się z czterech czynników, które w fazie procesu twórczego mogą się wielokrotnie przeplatać. Czynniki te to preparacja (przygotowanie), inkubacja, olśnienie oraz weryfikacja. ${ }^{66}$

Bardziej szczegółowej analizy procesu twórczego w kreacji plastycznej dokonał S. Popek. Opracował on model procesu kreacji plastycznej, w którym wyraźnie podkreśla ważną rolę wyobraźni w procesie twórczym jako głównego czynnika stymulującego a zarazem pobudzającego inne procesy psychiczne ${ }^{67} \mathrm{H}$. Semenowcz zaobserwował, iż w procesie twórczym siłą, która uruchamia dziecięcą ekspresję jest wyobraźnia. Wykazał on, iż wyobraźnia z twórczością są ściśle powiązane ze sobą. Zależność ich opiera się na kształtowaniu i rozwijaniu w procesie działalności twórczej jednostki. ${ }^{68}$

J.L. Singer pisał; „Na podstawie własnego doświadczenia wiem, że rozwinięta wyobraźnia [...]nie tylko umożliwia, ale w niektórych przypadkach wzmacnia proces tworzenia." ${ }^{\prime 69}$ Teoretycy i badacze wielokrotnie podkreślają ważną rolę wyobraźni w procesie twórczym. Podkreślają oni również znaczenie kontaktu z rzeczywistością, który jest niezbędny do podjęcia działania twórczego, ukierunkowanego na rozwiązanie problemu plastycznego. Posiadając bogatą wyobraźnię możliwe jest nie tylko wyobrazić sobie barwy, kształty czy odgłosy, ale również temperaturę oraz całą nieuchwytną atmosferę środowiska. Dzięki wyobraźni stajemy się bardziej czuli, emocjonalni oraz niezwykle wrażliwi na otoczenie.

Według S. Popka w procesie twórczym oprócz wyobraźni dużą rolę odgrywa także intuicja, która jest momentem szczególnej gotowości twórczej będąc jednocześnie koncentracją woli działania. Wizje wyobrażeniowe wyprzedzają proces kreacji weryfikując konkretne idee treściowo-artystyczne. ${ }^{70}$

Wielu psychologów jest głęboko przekonanych co do ważnej funkcji jaką pełni wyobraźnia w twórczości, jest jednym z mechanizmów obronnych osobowości co sprzyja twórczemu działaniu. Twórczość, która ma swoje źródło w wyobraźni staje się realizacją pragnienia, poprawą niezadowalającej rzeczywistości, stanowiąc jednocześnie zastępczą formę istnienia człowieka. ${ }^{71}$

Wyobraźnia uważna jest za istotny element różniący ludzi między sobą, jednocześnie sądzi się, że należy ona do zdolności niepowtarzalnych uzyskując miano oryginalności. Przez wielu psychologów uważa, jest za

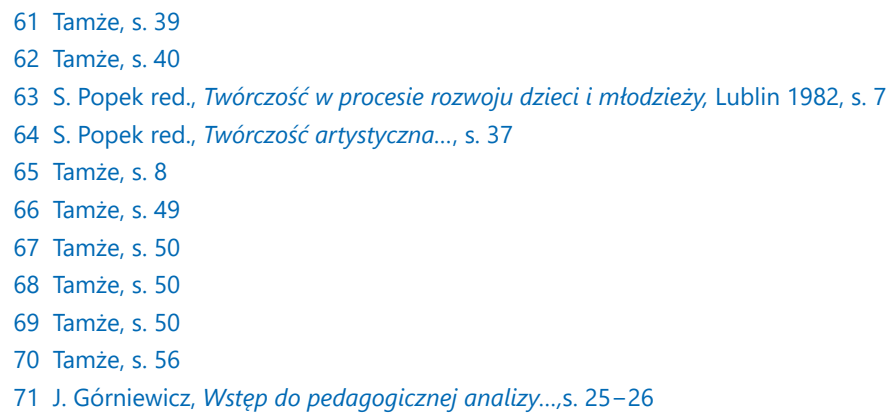


odmienną u wielu ludzi. Twórcze jej możliwości ujawniają się nie tylko w działalności plastycznej lecz także w wielu dziedzinach aktywności człowieka, również w kontaktach międzyludzkich.

Wyobraźnia jest zatem siłą psychiczną, władzą bądź zdolnością, w wyniku działania której powstają nowe obrazy czyli wyobraźnia. ${ }^{72}$

Ma ona związek nie tylko z aktywnością w sztukach wizualnych czy w odkryciach naukowych i technicznych, ale także i działalności w zakresie literatury i muzyki.

Przykład L.von Beethovena, który dokonywał ciągłych transformacji wyobrażeń w czasie tworzenia, czy A. Einsteina, który do rozwiązywania problemów fizyki teoretycznej posługiwał się obrazami wizualno przestrzennymi a więc wykorzystywał wyobraźnię. Podobnie jak N. Tesli, który przed skonstruowaniem maszyny prowadził wyobrażeniowy jej model. Niewątpliwą zaletą wyobraźni jest możliwość przechowywania i przetwarzania wielu informacji, pomaga w przekazywaniu informacji przestrzenno-wizualnych oraz uogólnionych. ${ }^{73}$

Wyobraźnia twórcza odgrywa ważną rolę we wszelkiej aktywności twórczej człowieka, związanej ze sztukami plastycznymi jak i z działalnością naukową, techniczną czy społeczną. Jest procesem umysłowym angażującym myślenie metaforyczne o silnym zabarwieniu afektywnym. ${ }^{74}$ Wyobraźnia bierze podstawowy udział w procesie twórczym człowieka, przyczyniając się jednocześnie do lepszego zrozumienia i poznania świata. Dzięki niej powstają dzieła oryginalne, nowe nietuzinkowe i unikatowe co i wzbogaca otaczający nas świat. Również w życiu codziennym człowieka jest nieodzownym jego towarzyszem. Pomaga w wyobrażeniu pewnych sytuacji, zdarzeń z życia codziennego bez których ciężko było by mu funkcjonować w świecie opierając się tylko na wzrokowych obrazach. I wreszcie wyobraźnia wzbogaca nas i nasze codzienne życie, daje nam inne spojrzenie na szarą rzeczywistość, wzmacnia duchowo i intelektualnie jednocześnie umożliwiając chwytanie całej radości życia.

\section{Rola twórczości plastycznej osób niepełnosprawnych umysłowo}

Sztuka jest tym co towarzyszy człowiekowi od początku istnienia bez względu na to jak ją będziemy definiować. Spełniała różne funkcje począwszy od funkcji estetycznej, poznawczej jak również diagnostycznej. Twórczość wpisana jest w codzienność człowieka nawet jeśli nie jest ona uświadomiona i pojmowana stricte w aspekcie artystycznym. Każdy człowiek przejawia potrzebę tworzenia, oddawania się jakiejś formie ekspresji. Przez twórczość angażujemy nasze emocje, myśli, potrzeby, pragnienia, które tkwią gdzieś głęboko w nas. Dzięki niej jesteśmy w stanie wydobyć z naszego wnętrza coś z czego czasem nie zdajemy sobie sprawy, że w nas jest. Twórczość ma wpływ na ujawnienie tłumionych emocji, rozładowanie napięć. Szczególnie istotne jest to w przypadku osób niepełnosprawnych intelektualnie, które mają problem z wyrażaniem swoich myśli. Priorytetem staje się znalezienie dla danej osoby obszaru, w którym poczuje się ona dobrze i bezpiecznie na tyle, by móc wyrazić siebie i wydobyć je na światło dzienne. Działalność twórcza staje się formą terapii, jak również elementem komunikacji z otoczeniem na bazie codzienności.

Stosowanie sztuk plastycznych przełamuje monotonię codziennego funkcjonowania osób niepełnosprawnych intelektualnie. Daje całą gamę doświadczeń estetycznych, kulturowych, poznawczych, twórczych i tych, dzięki którym dana osoba może wyrażać siebie i zakomunikować swoje potrzeby. Działania twórcze podwyższają również samoocenę i nastawienie osoby w stosunku do samej siebie, mając jednocześnie charakter terapeutyczny i rehabilitacyjny. Posługiwanie się formą plastyczną dla tych pełnosprawnych i niepełnosprawnych jest jednocześnie najprostszą odmianą kontaktu ze światem, pierwszą informacją, tworzeniem świadomych znaków w porozumiewaniu się z ludźmi. Malowanie, rysowanie, sklejanie, lepienie, wycinanie, ćwiczy koordynację wzrokowo-ruchową, doskonaląc przy tym precyzję dłoni, mięśni, ucząc utrzymywać uwagę. Działalność twórcza wycisza emocje jednocześnie motywując do działania. Wszystkie zajęcia plastyczne mają ogromne znaczenie dla uwrażliwiania dłoni dziecka, która jest podstawowym narzędziem poznania świata a i jej twórcze wykorzystanie poszerza zdolności rozumienia świata. Twórczość plastyczna dzieci niepełnosprawnych intelektualnie powoduje redukowanie napięć emocjonalnych, daje im radość i satysfakcję. W procesie twórczym zaangażowane są wszystkie sfery psychiki danej osoby, uczestniczą poszczególne receptory oraz aktywizowane są procesy poznawcze 
i emocjonalne. Zajęcia plastyczne mają duży wpływ na wszechstronny rozwój dzieci niepełnosprawnych umysłowo. Sprawiają im dużo przyjemności, wywołują radość i wiele przeżyć estetycznych. (Ryc. 3.)
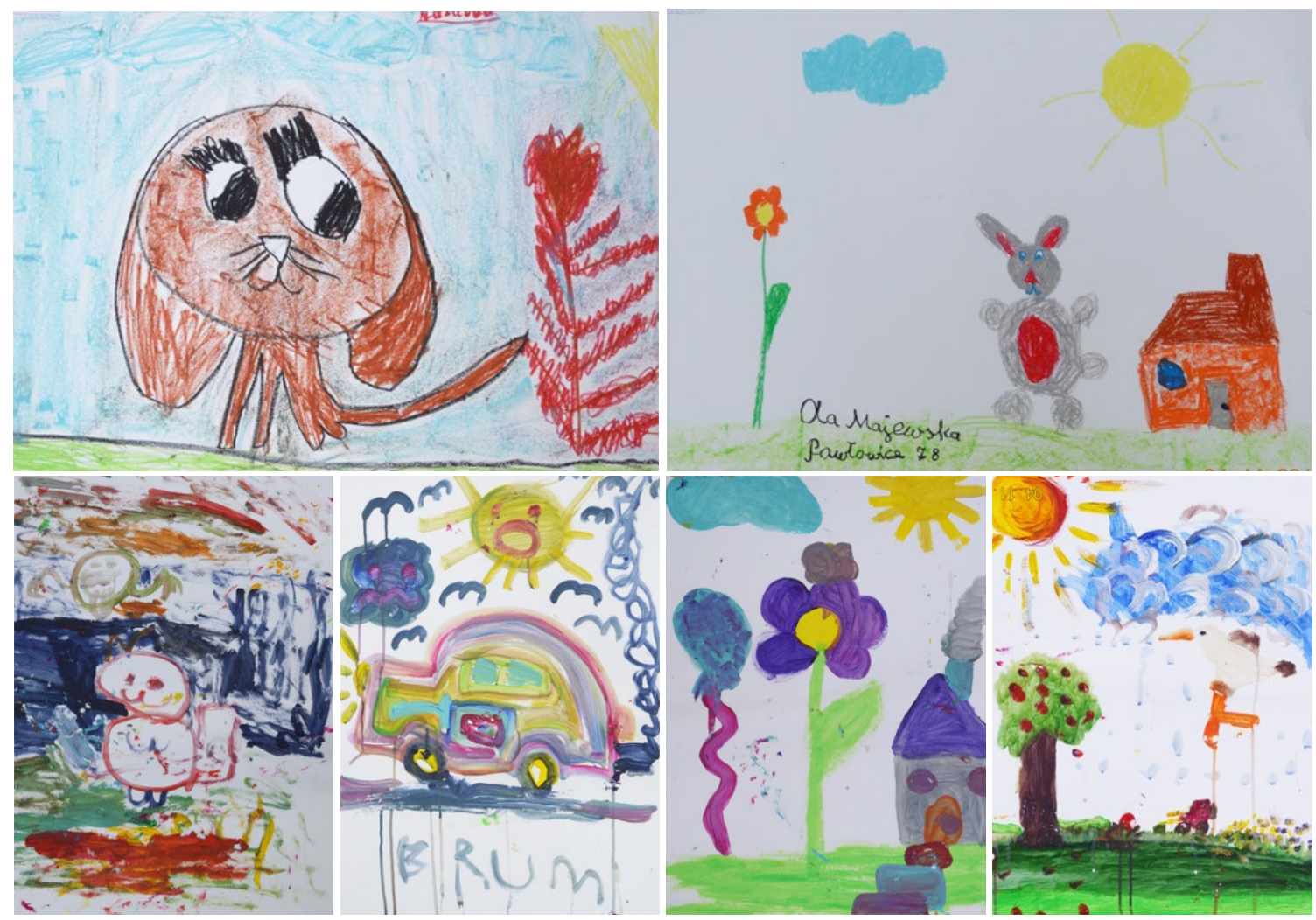

Ryc. 3. Prace dzieci niepełnosprawnych umysłowo z Zespołu Szkół nr 4 im. Janusza Korczaka w Lublinie w ramach warsztatów z rysunku i malarstwa zorganizowanych na Wydziale Budownictwa i Architektury Politechniki Lubelskiej w Lublinie

Art works of children with mental disabilities from School no. 4 names Janusza Korczak in Lublin under the workshops of drawing and painting organized in Faculty of Civil Engineering and Architecture, University of Lublin

Wykorzystanie twórczości plastycznej w celach leczniczych, dla uzyskania terapeutycznej zmiany, jest procesem umożliwiającym samopoznanie, jest swoistą przygodą z tworzeniem oraz twórczym myśleniem. Zapobiega występowaniu negatywnych emocji społecznych jednocześnie stymulując emocje korzystne, które mają wpływ na stan psychiczny. Terapia sztukami plastycznymi spełnia funkcję aktywizującą i odprężającą uwalniając od nadmiaru napięć. ${ }^{75}$

Zajęcia plastyczne są szansą na podjęcie działalności twórczej, na nadanie szerszego sensu swojemu istnieniu oraz na twórcze współdziałanie w grupie. Poprzez aktywne uczestnictwo w zajęciach dziecko zmniejsza napięcie psychofizyczne, odblokowuje hamowane emocje i napięcia. Ma możliwość odprężenia się oraz wyzwolenia wewnętrznej radości. Wyrównuje braki i ograniczenia psychofizyczne, pozwala zaakceptować siebie i innych oraz nadaje sens wzbogacając życie człowieka. Czynne uczestnictwo w zajęciach plastycznych daje możliwość nauki panowania nad własnym ciałem oraz ruchami nim wykonywanymi, a stosowanie różnorodnych technik plastycznych powoduje pozytywne zmiany ustrojowe, poprawia funkcjonowanie ośrodkowego układu nerwowego mięśni, kości i więzadeł. Zajęcia plastyczne mają ogromny wpływ na ćwiczenie i doskonalenie koordynacji wzrokowo - ruchowej. Równocześnie usprawniają orientacje przestrzenną i percepcję wzrokową. Praca 
twórcza pomaga kształtować osobowość, stwarza możliwości ujawniania uczuć, przejmuje nad nimi kontrolę i uwalnia od napięć, wpływa na samoocenę oraz poczucie własnej wartości. Jest to źródłem wiedzy o rozwoju umysłowym, emocjonalnym, estetycznym, społecznym i fizycznym człowieka. ${ }^{76}$ (Ryc. 4-7)

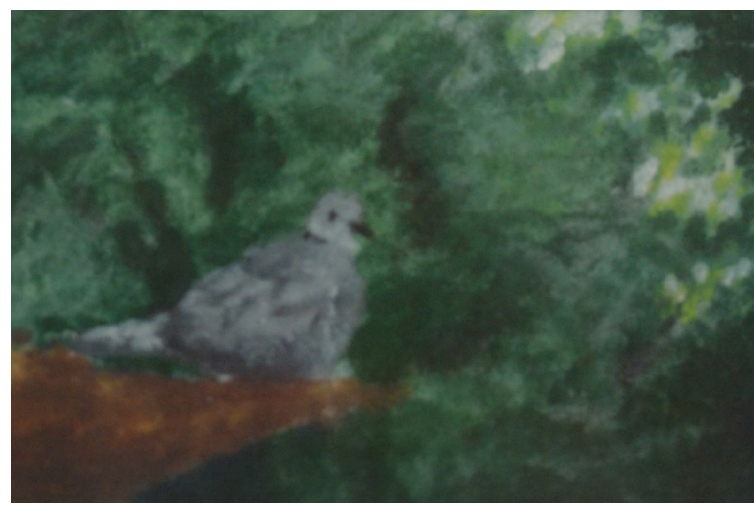

Ryc. 4. Agnieszka Stefaniak „Widok z okna” - farby akrylowe, Szkoła Powszechna w Lublinie

Agnieszka Stefaniak „Window view" - acrylic paint, Primary School in Lublin

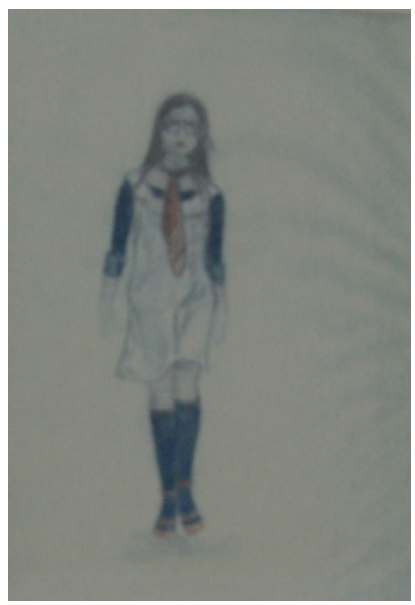

Ryc. 6. Agnieszka Stefanek "Strój mojego idola" - kredka Szkoła Powszechna w Lublinie

Agnieszka Stefanek "Outfit my idol" - pastel, Primary School in Lublin

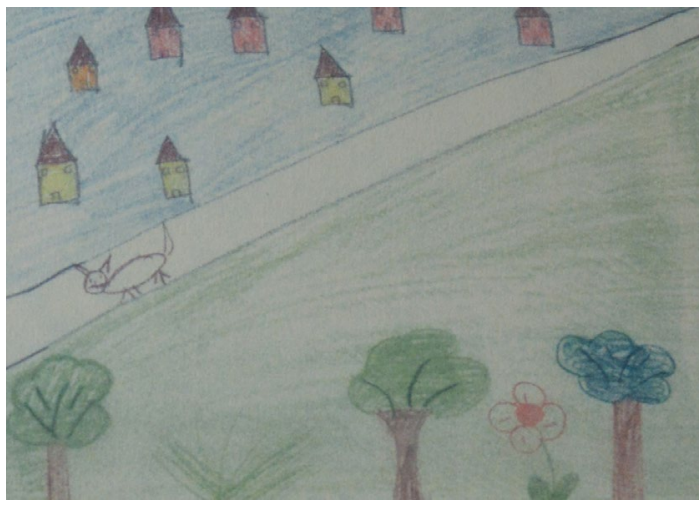

Ryc. 5. Agnieszka Miącz „Widok z lotu ptaka”- kredka, Szkoła Specjalna w Lublinie

Agnieszka Miącz „Window view” - acrylic paint, Special School in Lublin

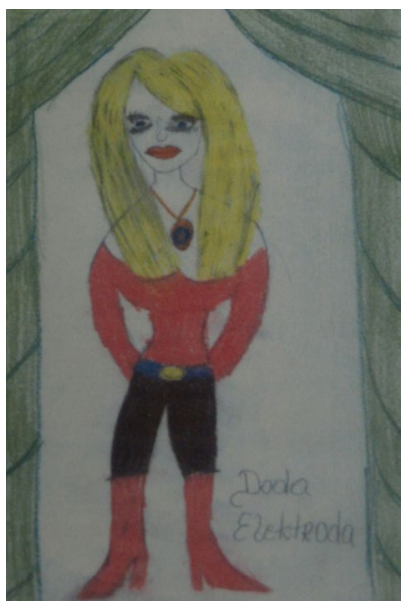

Ryc. 7. Sylwia Pietrzyk "Strój mojego idola" kredka Szkoła Specjalna w Lublinie

Sylwia Pietrzyk "Outfit my idol" - pastel, Special School in Lublin

\section{Bariery ograniczające rozwój wyobraźni}

Powszechnie wiadomo że, twórczość jest wynikiem działalności nielicznej grupy osób o wybitnych zdolnościach i predyspozycjach odbiegających od tych, jakie posiadają przeciętni ludzie. Ujmowana jest, jako efekt współdziałania systemu poznawczego, osobowościowego i aksjologicznego jednostki twórczej w powiązaniu z wspomagającym ją środowiskiem. ${ }^{77}$

Twórczość jest uwarunkowana zarówno czynnikami wewnętrznymi i zewnętrznymi. Nie ulega wątpliwości, że środowisko, w którym żyje człowiek może wpłynąć pozytywnie na jego postawę twórczą. Psychologowie zajmujący się twórczością uważają, że człowiekowi potrzebny jest tzw. klimat sprzyjający twórczości, czyli odpowiednia atmosfera społeczna i możliwości rozwoju intelektualnego. ${ }^{78}$ 
Twórcze wychowanie dziecka przyczynia się do ukształtowania własnego stylu życia. Aby jednak postawa dziecka była rzeczywiście twórcza musi ono posiadać określone cechy umysłu i osobowości, które należy w procesie wychowania kształtować. Dziecko powinno doznawać wielu bogatych i różnorodnych przeżyć, stymulujących jego umysł. Konieczny jest tu pewien stopień opanowania ważnych form myślenia i sposobów zdobywania wiedzy, jak również określone predyspozycje intelektualne i osobowościowe. Rodzice powinni starać się unikać zachowań, będących w sprzeczności z kształtowaniem umiejętności twórczych, a także wręcz niszczących inwencję twórczą dziecka.

Sztuka jest sposobem na wydobycie piękna, które tkwi w środku człowieka. Często nie zdając sobie sprawy z naszych możliwości, czy z możliwości drugiej osoby, dzięki sztuce odkrywamy jej duszę, nadajemy kształt jej człowieczeństwu i ukazujemy sens jej istnienia. Dzięki stworzeniu możliwości obcowania ze sztuką przyczyniamy się do ustawicznego rozwoju osobowości człowieka.

Psychologowie uważają, że człowiek z natury posiada zdolności twórcze, które może rozwijać poprzez odpowiednią współpracę ze środowiskiem. Jednak cyfryzacja współczesnego świata stanowi barierę, czynnik hamujący bądź uniemożliwiający rozwój wyobraźni a co za tym idzie i proces twórczy.

W. Dobrołowicz wyróżnia trzy grupy barier: przedmiotowe, podmiotowe i psychospołeczne ${ }^{79}$. Do pierwszej kategorii zalicza się przeszkody fizyczne, finansowe, materialne i techniczne. Bariery psychospołeczne dotyczą przeszkód tkwiących w strukturach społecznych, rządzących się prawami socjologicznymi, choć mieszczą się w psychice człowieka. Ujawniają się one głównie w błędnych przekonaniach, stereotypach i uprzedzeniach. Jednak największe znaczenie wśród czynników utrudniających proces twórczy stanowią bariery tkwiące w samej jednostce. Wyróżnia się tu cztery grupy barier: percepcyjne, umysłowe, emocjonalno-motywacyjne i przeszkody osobowościowe. Bariery percepcyjne dotyczą procesów spostrzegania, występujących przede wszystkim w schematach spostrzeżeniowych, polegających na dostrzeganiu nie rzeczywistych lecz oczekiwanych przedmiotów, zjawisk i rzeczy. Często spotykanym inhibitorem jest tkwiąca w podmiocie obronność percepcyjna, charakteryzująca się nadmierną selektywnością bodźców, którą podmiot dokonuje zgodnie z przewidywanymi rezultatami. Bariery umysłowe odnoszą się do myślenia i wyobraźni a ujawniają się w sztywności, inercji (bezładności) i tendencyjności w myśleniu. Bariery emocjonalno-motywacyjne należą do głównych przeszkód postawy twórczej człowieka. Dotyczą one braku wiary w powodzenie przedsięwzięcia, lęku przed nieznanym, niepowodzeniem i ośmieszeniem się. Natomiast przeszkody osobowościowe wynikają z nieadekwatnego obrazu samego siebie i otaczającej rzeczywistości, braku wiary w swoje możliwości, postawy pesymistycznej, słabej woli, nieumiejętności zorganizowania i rozplanowania codziennych zajęć, braku odwagi, nadmiernego konformizmu oraz lenistwa. ${ }^{80}$

Obecnie staje się normą posiadanie laptopa bądź tabletu przez każdego członka rodziny. Korzystanie z komputera daje wiele możliwości zarówno dzieciom, jak i dorosłym, stanowiąc jednocześnie barierę ograniczającą człowieka w wielu aspektach życia. Komputer, laptop czy telefon na wiele sposobów ułatwia nam życie, jednocześnie prowadząc do licznych dysfunkcji u osób zdrowych.

Wyobraźnia odgrywa istotną rolę w prawidłowym rozwoju dziecka, gdyż dzięki niej wędruje tam, gdzie w rzeczywistości nie może. Stymuluje ona działalność jednostki i stanowi teren jego marzeń, pobudza do działania w realnym świecie. Ma w niej możliwość poznania swoich uczuć odreagowania smutku, czy niepokoju, a także nastawienia na siebie i do innych. Dzięki wyobraźni dziecko potrafi przeżyć jakąś sytuację dotychczas odbieraną przez nie jako trudną, a następnie zilustrować to rysunkiem co działa na nie pozytywnie. Internet, tablet czy telefon „zabijają" w dziecku twórcze myślenie, pozbawiają bodźców werbalnych, twórczej działalności czy ekspresji wyrażania uczuć.

Okres dzieciństwa jest ważnym etapem dla rozwoju wyobraźni twórczej, która rozwija się w wyniku symbolicznych zabaw dziecięcych. Dziecko w zabawie dokonuje "rozszerzenia siebie”, przy udziale wyobraźni przeobraża rzeczywistość, która umożliwia mu zaspokojenie własnych pragnień i życzeń. Niedostatek wiedzy dziecka powoduje, że świat przedstawiony w zabawach jest niepełny. I tylko dzięki wyobraźni te luki zostają wypełnione tak aby umożliwić dziecku dalszą zabawę. A wypełnia je wątkami ze świata bajek, które jeszcze bardziej wzbogacają żywą z natury i twórczą wyobraźnię dziecka. To właśnie wyobraźnię zaludniają postacie z bajek, opowiadań czy bohaterowie filmowi. 
A więc twórczość artystyczna wzbogaca osobowość dzieci, ich sposób odczuwania, przeżywania i przekształcania świata rzeczywistego. Dziecko będąc twórcą własnej sztuki jest jednocześnie jej odbiorcą. Poprzez bezpośredni kontakt z dziełami sztuki nie tylko wzbogaca swoje doświadczenie, ale odkrywa inne wartości, które pozwalają budować mu swoją osobowość. Te dzieła pokrzepiająco dla wyobraźni, a obcowanie ze sztuką wzbogaca wyobraźnie o nowe doznania estetyczne. Tak więc sztuka staje się ważnym narzędziem kształtowania wyobraźni, która uznawana jest z jednej strony za źródło sztuki oraz drogę do jej poznania. To właśnie sztuka i twórczość artystyczna będąc wytworem wyobraźni jest środkiem jego wzbogacania i kształtowania. To wyobraźnia w sztuce dziecka uzupełnia to co wydaje się niezrozumiałe, skrywane rozjaśnia to, co wydaje się mgliste i nieznane.

W dzisiejszych czasach codzienna przestrzeń życia rodzaj kontaktów społecznych oraz ich obszar zmieniają się bardzo gwałtownie. Dziecięce przeżycia i doświadczenia kształtują obecnie pojawiające się nowe źródła o niezwykle zróżnicowanym charakterze. To właśnie media elektroniczne tuż obok tego, co dzieje się w bezpośrednim otoczeniu tworzą jego środowisko życia. Dzieci od najmłodszych lat codziennie, z dużą fascynacją i zainteresowaniem zanurzają się w świat Internetu, który różni się od tego realnego. Jest to świat trudny do "uchwycenia", przedstawiana w niej rzeczywistość jest pełna skrótów, uproszczeń i kopii co upośledza jego wyobraźnię i myślenie twórcze. Ta odrealniona rzeczywistość jest dla dziecka bardzo atrakcyjna i ciekawa poprzez swoją zmienność i różnorodność lansowanych w niej wzorów zachowań, obrazów i poglądów. Producenci przekonują, że rozwijają one wyobraźnię oraz zdolność do abstrakcyjnego myślenia, że są idealnym medium przekazywania treści z zakresu logiki, matematyki czy ekonomii. Prawda jest taka, że bardzo silnie oddziałują na psychikę, łatwo uzależniając, a w przypadku brutalnych gier uczą nieetycznych i agresywnych zachowań.

Szybki postęp technologiczny, którego jesteśmy świadkami, nie pozostaje bez wpływu na rozwój dziecka. Rodzice już u niemowlaków zauważają szczególne zainteresowanie telefonem czy tabletem, które kuszą dźwiękami i kolorami. Podczas zabawy, która poza sprawieniem radości rozwija i uczy, wykorzystywane są wszystkie zmysły dziecka, czego nie można osiągnąć grając na tablecie, konsoli czy telefonie.

Podczas używania elektronicznych urządzeń wykorzystywany jest głównie wzrok. Nawet dotyk jest ograniczony. Węch? Brak. Słuch? Dźwięk tylko z jednego źródła. Bardzo ograniczone czucie głębokie. Nie ma tu jakiegokolwiek porównania z zabawą na świeżym powietrzu, czy działaniami plastycznymi podczas, których wykorzystywane są wszystkie zmysły.

Korzystanie przez dziecko w dużej mierze wyłączne z tabletu, telefonu czy komputera może przyczynić się do obniżenia czułości pozostałych zmysłów. Dodatkowo nowoczesne urządzenia mogą wyrządzić szkodę dłoniom i palcom najmłodszych dzieci. Zabawa tabletem czy smartfonem w dłuższej perspektywie czasu nieść może poważne konsekwencje zdrowotne, gdyż dziecko używając wyłącznie ekranów dotykowych, nie wykształca mięśni, koniecznych do opanowania zdolności pisania, rysowania czy malowania. To wszystko przyczynia się do powstania nowych dysfunkcji u dzieci.

Dziecko, które długo korzysta z komputera lub tabletu jest narażone na wiele dysfunkcji. Jednak najbardziej zagrożona jest jego sylwetka. Dzieci odczuwają bóle pleców, kręgosłupa i usztywnienie mięśni z powodu nieprawidłowej pozycji ciała podczas korzystania z komputera lub tabletu. Dodatkowo mogą cierpieć na dolegliwości związane ze wzrokiem, np. podrażnienie błony śluzowej oczu, zaburzenia widzenia, zmęczenie, zaczerwienienie i pieczenie oczu, a także zawroty i bóle głowy.

Komputer lub tablet używany w niewielkim zakresie wspomaga naukę i ułatwia zdobywanie wiedzy, umiejętności czytania i pisania. Jednak w wyniku nagromadzonej liczby informacji, dziecko traci umiejętność ich selekcjonowania.

Nieodpowiedni zakres tematyczny może spowodować zaburzenia emocjonalne i społeczne. Dzieci miewają również problem z odróżnieniem świata gier czy bajek od świata realnego, w którym funkcjonują na co dzień. Dzieci wolą czynić "cuda" np. piec ciasteczka, budować domy, ścigać się na quadzie, przesuwając palcami po ekranie tabletu lub myszką komputerową niż bawić się klockami i rysować. Komputery czy tablety pozbawiają także zdolności koncentracji i komunikacji. Zanika umiejętność ładnego pisania i mówienia. Dodatkowo dzieci te są także aspołeczne z powodu braku kontaktu z innymi, czują się wyobcowane i nie umieją stworzyć relacji z rówieśnikami.

Procesów rozwoju technologii komputerowej i informacyjnej nie da się zahamować i zawsze będzie ona atrakcyjna dla dzieci i młodzieży. Dlatego też problematyka zagrożeń powinna być znana wszystkim, którzy mają jakikolwiek wpływ na wychowanie, dla których dobro dziecka i jego prawidłowy rozwój jest najważniejszy. 


\section{Podsumowanie}

Organizacja czasu wolnego naszych dzieci ma ogromny wpływ na rozwój ich osobowości, pasji i kreatywności. Jest jednak bardzo trudna. Często rodzice zamiast proponować wyszukane rozwiązania, pozwalają dziecku zająć się komputerem lub tabletem nawet przez kilka godzin w ciągu dnia. Dziecko powinno wykonywać zajęcia twórcze, zaspakajać swoje potrzeby, rozwijać indywidualne zainteresowania. Dobrze zorganizowany czas powinien zapewnić mu prawidłowy rozwój fizyczny i intelektualny, emocjonalny i społeczny. Powinien także regenerować organizm malucha.

Współcześnie wielu rodziców żyje w ciągłym pośpiechu, w warunkach towarzyszących im stresu i braku czasu. Z tego powodu coraz więcej dzieci jest skazanych na samotne popołudnia. Samotnie czyli przed komputerem, grając w gry, czy oglądając bajki bez żadnych ograniczeń. Komputery i tablety przeniknęły do życia społecznego, pokonując ograniczenia wiekowe. Obecnie towarzyszą nawet najmłodszym, stając się częścią ich codzienności. Rodzice zdają się zapominać, że długie spędzanie czasu przed komputerem, tabletem lub telewizorem niesie zagrożenia dla rozwoju ich pociech, wpływając na niego negatywnie.

Zatem śmiało możemy stwierdzić iż, wyobraźnia jest umiejętnością każdego człowieka, która powinna być kształtowana już od najmłodszych lat, poczynając już od wieku dziecięcego. Pomaga nam w mniej lub bardziej szczegółowym tworzeniu w umyśle sytuacji hipotetycznych bądź rzeczywistych przydatnych w dorosłym życiu. Jest ona umiejętnością wytwarzania w umyśle pewnych bodźców odbieranych przez różne zmysły człowieka. Wyobraźnia artystyczna jest umiejętnością przekazywania swoich wrażeń i wyobrażeń, która powinna być kształtowana również na lekcjach plastyki na każdym etapie kształcenia szkolnego. Dlatego należałoby pomóc w kształtowaniu wyobraźni i pobudzaniu do aktywności twórczej dzieci i młodzieży. Istotne jest stworzenie sprzyjających warunków do pracy twórczej.

W rozwijaniu wyobraźni uczniów niezmiernie ważną rolę odgrywa nauczyciel zachęcający do twórczej aktywności, która powinna przebiegać w sposób naturalny, autentyczny odpowiedni, co do rozwoju dziecka. Zagadnienia teoretyczne jak i formalne powinny być przekazywane stopniowo z odpowiednim objaśnieniem i wprowadzeniem do nowego zagadnienia niezbędnego w twórczej działalności dzieci i młodzieży.

\section{Biografia}

[1] Baudelaire Ch., Szkice krytyczne, Wrocław 1961, s. 93-96.

[2] Berlyne E.D., Struktura i kierunek myślenia, Warszawa 1969

[3] Bobra Por. M. Sangs of Innocence and Experience, (w) Romantic Imaginacjon, London 1961, s. 25-31.

[4] Bronowski J., Źródła wiedzy i wyobraźni, Warszawa 1984, s. 24-31.

[5] Chmielewski Por. P., Geneza fantazji, Warszawa 1873, s. 47

[6] Dobrołowicz W., Psychologia o myśleniu intuicyjnym, „Studia Filozoficzne”, 1981, ur U, ss. 105-121

[7] Dobrołowicz W., Psychika i bariery, Warszawa 1993.

[8] Dobrołowicz W., Antykreatywność - bariery psychiczne i psychospołeczne,w: Twórczość - wyzwanie XXI wieku, E. Dąbrowska, A. Niedźwiecka (oprac.), Kraków 2003.

[9] Dobrołowicz W., O myśleniu intuicyjnym, "Studia Filozoficzne”, 1981, nr U, ss. 105-121.

[10] Gloksina W., Uwarunkowania psychicznego rozwoju dziecka, Warszawa 1988.

[11] Grzywacz M. - Kaczyńska, Psychologia dla każdego, Warszawa, s. 91

[12] Górniewicz J., Wstęp do pedagogicznej analizy problematyki wyobraźni, Toruń 1991, s. 22-26

[13] Hornowski B., Rozwój inteligencji i uzdolnień specjalnych, Warszawa 1978, s. 47,102.

[14] Jacobs N.J., Maimon's Theory of the Imagination, (w) Studies in Philosophy Jerusalem 1960, s. $250-257$.

[15] Kant J., Krytyka władzy sądzenia, Warszawa 1986, s. 124-129.

[16] Klimasiński K., Ksztatcenie wyobraźni konstrukcyjnej, Warszawa 1978, s. 10.

[17] Kondas O., Psychologia kliniczna, Warszawa 1984, s. 183-183

[18] Łukaszewski W., Szanse rozwoju osobowości, Warszawa 1984, s. 254.

[19] Łuszczak M., Możliwości kształtowania wyobraźni twórczej studentów, Cieszyn 1997, s. 47, 51.

[20] Łukasiewski W., Szanse rozwoju osobowości. Warszawa 1983, s. 253-254.

[21] Morawski Por. S., Poglądy Józefa Kremera na sztukę, (w:) Studia historii myśli estetycznej XVIII i XIX w., s. 260. 
[22] Nałczadżjan A., Intuicja a odkrycia naukowe, Państwowy Instytut Naukowy, 1979 Warszawa, s. 46-47.

[23] Nowicki T.W., Zarys psychologii, Warszawa 1979, s. 92.

[24] Popek S., R. Tarasuk, pod red., U podstaw edukacji plastycznej, Lublin 2000, s. 86.

[25] Popek S. red., Twórczość w procesie rozwoju dzieci i młodzieży, Lublin 1982, s. 7.

[26] Popek S. red., Twórczość artystyczna wychowania dzieci i młodzieży, Warszawa 1985 s. 37.

[27] Popek S., R. Tarasiu red., U podstaw edukacji plastycznej, Lublin 2000 s. 86-87

[28] Przetacznikowa M., G. M. Jarża, Psychologia...op.cit.,s. 102

[29] Ribot T., O wyobraźni twórczej, Warszawa 1901, s. 5-6, 112

[30] Rozet J., Psychologia fantazji, Warszawa 1982, s. 20.

[31] Ribot Th., O wyobraźni twórczej Warszawa 1901, s. 9,10, 112

[32] Rubinsztejn S.L., Podstawy psychologii ogólnej. Warszawa 1962, s. 432-442, 438

[33] Rukin J., O wyobraźni (w) Sztuka - Społeczeństwo - Wychowanie, Wrocław 1977, s. 49-50, 63

[34] Sławska K., Myśl w działaniu - psychologia myślenia, Warszawa 1971, s. 171-172

[35] Singer J.L., Marzenia dzienne, Warszawa, 1980, s. 152-153

[36] Szuman S., O budzeniu i pogłębianiu wrażliwości młodzieży na sztukę, Nowa Szkoła" 1961 nr 5.

[37] Suchodolski B., Wychowanie i strategia życia, Warszawa 1983, s. 183.

[38] Shelley P. B., Obrona poezji, (w) Manifest romantyzmu 1790-1830 Op.cit.,s. 101.

[39] Szewczuk W. (red.), Stownik psychologiczny, Warszawa 1979, s. 328 (hasło 1,2 i 4 opracował E. Szewczuk, W. Szewczuk).

[40] Szczepański J., Sprawy ludzkie, Warszaw 1984, s. 147-149.

[41] Troskoliński A.T., O twórczości. Piśmiennictwo naukowo-techniczne, Warszawa 1982, s. 41,48

[42] Trojanowska - Kaczmarska A., Dziecko i twórczość, Wrocław - Warszawa - Kraków - Gdańsk 1971

[43] Tyszkowa M., Baśń w życiu i rozwoju dziecka, "Wychowanie w Przedszkolu”, 1974, nr 4, s. 199.

[44] Witwicki W., Psychologia, t.l, Warszawa 1962, s. 336-340, 379

[45] Vico G., Nauka nowa, Warszaw 1966, s. 475-476.

[46] Young E., Propozycje dotyczące oryginalnej twórczości, (w:) Teoria ba dań literackich za granica Antologia, t. 1, (Wybór i opracowanie S.Skwarczyńska), Kraków 1965, s. 165.

[47] Zakski Z. L., Rola wyobraźni w twórczości naukowej, Hanower 1946, s. 9-10

[48] https://pl.wikipedia.org/wiki/Sztuka_prehistoryczna

[49] http://historiasztuki.com/historia-sztuki-w-pigulce.html

[50] https://pl.wikipedia.org/wiki/Malarstwo

\title{
Role of imagination in a creativity process and a threats of the modern world
}

\begin{abstract}
In all areas of creative activities imagination is an essential element of life and man's functioning. In many situations in our life it is an inherent element used in many cases more or less consciously. It allows you to create images that have no equivalents in any impressions presenting the basis for creativity and all human activity. Imagination is a natural extension of sight. It is a peculiar ability to form images, encouraging creative reflection and activities of young people. Nowadays a human being is constantly bombarded with an increasing numberof sounds and images, which "choke" the natural evolution of imagination. The fast technological progress, that we witness does not remain without influence on the development of creative thinking, it creates barriers that can restrain a human being.
\end{abstract}

Keyworlds: imagination, creative thinking, barriers, the creative process 